\title{
EFFECT OF HIGH-PRESSURE PROCESSING ON MICROBIAL QUALITY OF SKIMMED MILK
}

\author{
Marika Liepa, Jelena Zagorska\#, Ruta Galoburda, and Svetlana Kostascuka \\ Faculty of Food Technology, Latvia University of Life Sciences and Technologies, 22 Rīgas Str., Jelgava, LV-3004, LATVIA \\ \# Corresponding author, jelena.zagorska@ Ilu.lv \\ Communicated by Inga Ciproviča
}

\begin{abstract}
High pressure processing (HPP) is an alternative to traditional thermal treatment and can be used in the dairy industry for increasing the microbiological safety of milk and for preserving its biologically active substances. HPP effectiveness in providing microbiological quality of product is still under discussion; thus, the aim of the study was to evaluate the effect of HPP technology on microbiological quality of skimmed milk. Raw, pasteurised $\left(78^{\circ} \mathrm{C}, 15-20 \mathrm{~s}\right)$, HPP treated (250 MPa, $15 \mathrm{~min} ; 400 \mathrm{MPa}$, $3 \mathrm{~min} ; 400 \mathrm{MPa}, 15 \mathrm{~min} ; 550 \mathrm{MPa}$, $3 \mathrm{~min}$ ) and skimmed milk, processed by combining pasteurisation and HPP were analysed and compared. The total plate count (LVS ISO 4833-1:2013) and presence of coliforms (LVS EN ISO 16654:2002) were determined in analysed skimmed milk samples. Significant decrease $(\mathrm{p}<0.05)$ of colony forming units (CFU) was observed in samples processed by combining two treatment types: pasteurisation and HPP. The minimum treatment parameters for shelf-life extension of skimmed milk were determined: pressure not less than $400 \mathrm{MPa}$ and holding time at least 15 minutes.
\end{abstract}

Key words: high pressure, skimmed milk, microbial load reduction.

\section{INTRODUCTION}

Milk is one of the most frequently sold foods worldwide. The nutritional composition, high water content and neutral $\mathrm{pH}$ turn milk into an adequate media for microbial development of vegetative and sporulating microorganisms (Chopde et al., 2014). Nowadays, milk and dairy products are treated with a specific time temperature combination, to provide acceptable safety and shelf-life. The three basic approaches to heat treatment of raw milk, pasteurisation $\left(72{ }^{\circ} \mathrm{C}\right.$ for $\left.15-20 \mathrm{~s}\right)$, ultrapasteurisation $\left(80-90{ }^{\circ} \mathrm{C}\right.$ for $15 \mathrm{~s}$ ) and ultra-high temperature (UHT) $\left(135-150{ }^{\circ} \mathrm{C}\right.$ for 1 to 4 $\mathrm{s}$ ), differ primarily in their underlying purpose (Chawla et al., 2011; Fitria et al., 2015). Processing at high temperature lowers the nutritional quality of foods because many nutrients are heat labile. To overcome this problem, several non-thermal processing or "cold pasteurisation" techniques including high hydrostatic pressure (HHP) technology have been developed.

One of the first scientific reports on high pressure (HP) applications for food was written by Hite (1899) on shelf-life extension of milk, and recently on the HP effect on foodborn microorganisms by subjecting milk to a pressure of $650 \mathrm{MPa}$ (Heinz and Buckow, 2009; Ghasemkhani et al., 2014). Since then, the application of HP treatment has been broadened to other food products such as meats, fish and shellfish, fruit and vegetable products, cheeses, salads, grain products, and liquids including juices, sauces, and soups (Heinz and Buckow, 2009; Bello et al., 2014).
The high pressure process is characterised by three parameters: temperature $(\mathrm{T})$, pressure $(\mathrm{p})$, and exposure time $(\mathrm{t})$. In comparison, the heat preservation process is based on only two parameters $(\mathrm{T}, \mathrm{t})$. The three processing parameters allow great flexibility in the design of the process (Heinz and Buckow, 2009; Naik et al., 2013). High pressure processing (HPP) combining high pressure (up to $1000 \mathrm{MPa}$ ) and sometimes heating (above $60^{\circ} \mathrm{C}$ ) has been considered equal to sterilisation, which extends shelf life of foodstuff due to its ability to inactivate bacterial spores at reduced heat and thereby preserving desirable functional properties of foods better than conventional thermal processing (Heinz and Buckow, 2009; Fitria et al., 2015).

A major function of HPP of food is the destruction of microorganisms. HP inactivates most of the spoilage and pathogenic bacteria present in milk. Most of the studied bacteria are inactivated in milk after treatment at 400-600 MPa (Patterson, 2005; Rodriguez et al., 2005; Yaldagard et al., 2008; Zhang and Mittal, 2008; Udabage et al., 2010). Temperature and HP can cause considerable microbial inactivation when applied alone, but it has been observed that these two treatments combined can confer dramatically improved inactivation levels, particularly with regard to bacterial spores (Considine et al., 2008).

The use of non-thermal methods for food preservation is due to consumer demands for microbiological safe products without changes in the sensory and nutritional quality of the product (Muñoz-Cuevas et al., 2013). The development of 
food ingredients with novel functional properties offers the dairy industry an opportunity to revitalise existing markets and develop new ones. HPP effectiveness on microbiological quality of product is still under discussion, and thus the aim of the study was to evaluate effect of HPP technology on microbiological quality of skimmed milk.

\section{MATERIALS AND METHODS}

The study was carried out in laboratories of the Faculty of Food Technology, Latvia University of Agriculture, from September to December 2015.

Individual cow milk samples were collected from the morning milking during sampling procedure of milk quality monitoring according to the standard LVS 175:1999 'Sampling of raw milk'. After collection, milk samples were transported to the laboratory. Immediately after transport to the laboratory, milk was heated to $40-45^{\circ} \mathrm{C}$ for subsequent cream separation in a conventional milk centrifuge. After separation, skimmed milk $(100 \pm 10 \mathrm{~g})$ was filled in $70 \times$ $200 \mathrm{~mm}$ sized vacuum pouches with $65 \mu \mathrm{m}$ thickness. The pouches of skimmed milk were hermetically sealed using a chamber type vacuum packaging machine Multivac C350 (MULTIVAC Sepp Haggenmüller SE \& Co. KG, Wolfertschwenden, Deutschland).

High pressure (HP) and thermal processing (TP). In high-temperature short-time (HTST) pasteurization, milk (TP Milk) was held at $78{ }^{\circ} \mathrm{C}$ for $15-20 \mathrm{~s}$. Milk samples were pressurised in isostatic press (STANSTED fluid power LTD, Stansted, Harlow, UK) with a pressure chamber of 10 $\mathrm{cm}$ diameter and $23 \mathrm{~cm}$ length. The pressure chamber and the pressurisation medium inside were adjusted to the initial temperature of $20 \pm 1{ }^{\circ} \mathrm{C}$ with a constant flow of water. HP processing was compared to thermal processing (TP), as this is the most common option used for thermal treatment of milk.

Analysis of milk samples. In total, 30 skimmed milk samples were analysed (Table 1). After treatment (pasteurisation and/or high pressure processing) all milk samples were stored at $4 \pm 2{ }^{\circ} \mathrm{C}$ for 7 days. Milk samples were analysed after 2, 4, 5, 6, and 7 days of storage.

Microbiological parameters. The milk samples were serially decimally diluted with Maximum Recovery Dilutent according to the standard LVS EN ISO 6887-5:2011 "Microbiology of food and animal feeding stuffs - Preparation of test samples, initial suspension and decimal dilutions for microbiological examination — Part 5: Specific rules for the preparation of milk and milk products (ISO 6887-5:2010)" and appropriate dilutions were plated on agars. The plate counting method was used for microbial assessment. The total plate count of mesophylic aerobic and facultative anaerobic microorganisms was determined on Nutrition Agar medium (Nutrient Agar Ref. 01-140) (dilutions $1: 1000 ; 1: 10000)$ in conformity to the standard method LVS EN ISO 4833:2013 "Microbiology of food and
Table 1

MILK SAMPLES INCLUDED IN THE STUDY

\begin{tabular}{l|c|c}
\hline \multicolumn{1}{c}{ Sample code } & $\begin{array}{c}\text { Pressure, } \mathrm{MPa} / \\
\text { Temperature, }\end{array}{ }^{\circ} \mathrm{C}$ & Holding time \\
\hline Control & Raw skimmed milk & - \\
$\mathrm{TP}$ & $78^{\circ} \mathrm{C}$ & $15-20 \mathrm{~s}$ \\
HP 250/15' & $250 \mathrm{MPa}$ & $15 \mathrm{~min}$ \\
HP 400/3' & $400 \mathrm{MPa}$ & $3 \mathrm{~min}$ \\
HP 400/15' & $400 \mathrm{MPa}$ & $15 \mathrm{~min}$ \\
HP 550/3' & $550 \mathrm{MPa}$ & $3 \mathrm{~min}$ \\
TPHP* 250/15' & $250 \mathrm{MPa}$ & $15 \mathrm{~min}$ \\
TPHP* 400/3' & $400 \mathrm{MPa}$ & $3 \mathrm{~min}$ \\
TPHP* 400/15' & $400 \mathrm{MPa}$ & $15 \mathrm{~min}$ \\
TPHP* 550/3' & $550 \mathrm{MPa}$ & $3 \mathrm{~min}$ \\
\hline
\end{tabular}

* TPHP, combination of thermal and high pressure processing, TP completed at $78{ }^{\circ} \mathrm{C}$ for $15-20$ seconds.

animal feeding stuffs - Horizontal method for the enumeration of microorganisms - Colony-count technique at 30 degrees C'. Coliforms were determined according to LVS EN ISO 16654:2002 "Horizontal method for detection of Escherichia coli O 157". Colonies were counted and the number of CFUs was calculated using an automatic colony counter Acolyte (Synbiosis, UK, Cambridge, UK).

Data analysis. The obtained data were processed using Microsoft Excel; differences among results were considered significant if $p<0.05$.

\section{RESULTS}

The first step of our study was to determine the effect of various treatment parameters on milk microbiological quality. The total number of microorganisms in the raw milk sample was $130000 \mathrm{CFU} / \mathrm{ml}$ (5.11 log CFU/ml). Both treatment methods (high-pressure and pasteurisation) resulted in the desired result of decreased total counts of microorganisms in all milk samples (Fig. 1).

The total plate count in thermally processed (pasteurised) skimmed milk decreased significantly $(p<0.05)$ compared with the control sample (from $5.11 \mathrm{log} \mathrm{CFU} / \mathrm{ml}$ to $3.58 \mathrm{log}$ $\mathrm{CFU} / \mathrm{ml}$ ), respectively by $97.1 \%$. The lowest total counts of microorganisms were found in the HP 550/3 treatment $1.53 \mathrm{CFU} / \mathrm{ml}$ (99.7\% less compared with the control sample). In milk treatments HP 250/15', HP400/3', and HP $400 / 15$ the amount of total bacteria was higher: respectively, $3.6 \log \mathrm{CFU} / \mathrm{ml}, 3.48 \mathrm{log} \mathrm{CFU} / \mathrm{ml}$, and $2.56 \mathrm{log}$ $\mathrm{CFU} / \mathrm{ml}$. After two storage days, microbial growth was observed in all milk treatments, except in the HP 550/3 treatment. The number of microorganisms in raw milk during its storage significantly increased. However, treatment HP $550 / 3$ the total count of microorganisms was stable at 1.53 $\log \mathrm{CFU} / \mathrm{ml}$ and compared with other treatments it was the most effective. 

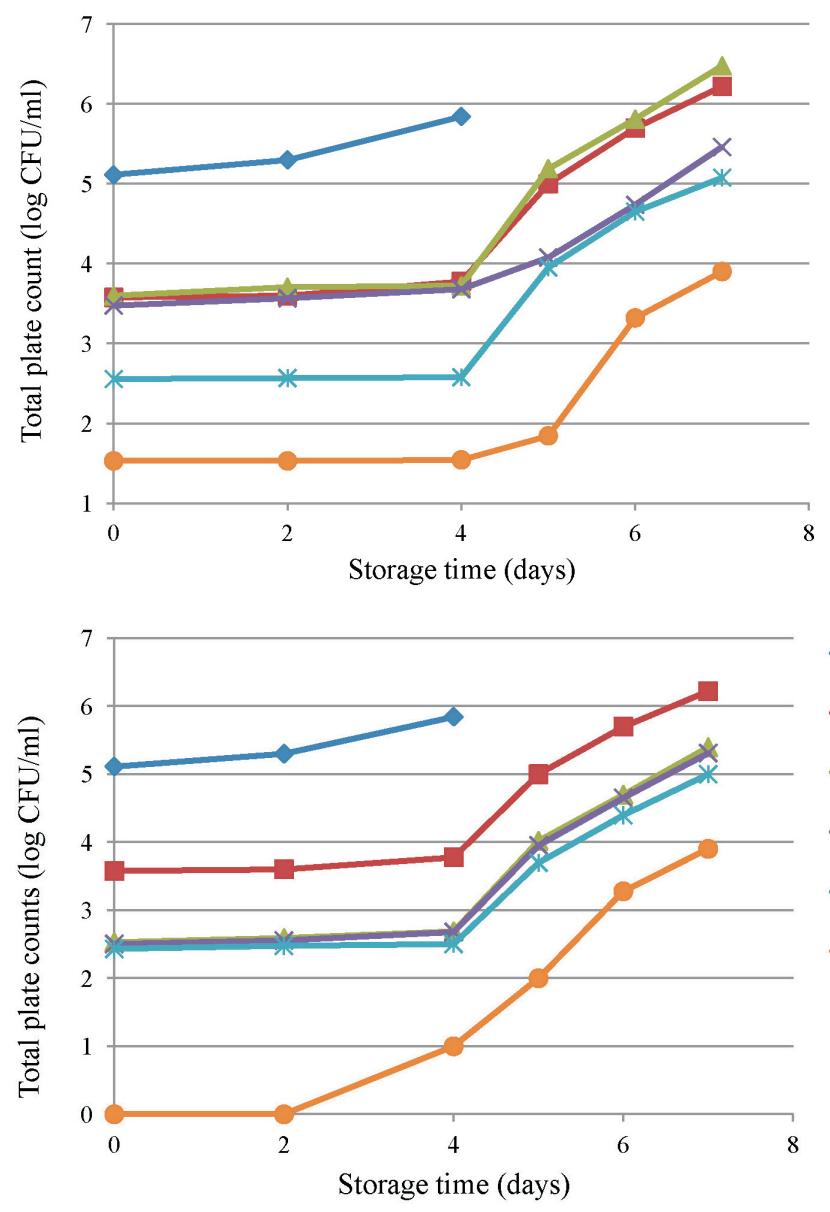

After four days of storage, the number of microorganisms in the control was $5.85 \log \mathrm{CFU} / \mathrm{ml}$, so a decision was made not to proceed with raw milk analysis. In pasteurised skimmed milk, faster growth of microorganisms (3.78 log $\mathrm{CFU} / \mathrm{ml}$ ) had occurred compared to HP treated milk. After five days, microbial growth continued and in three (TP, HP 250/15', and HP 400/15') of five milk treatments there was rapid development of total bacteria counts (from 3.70 to $5.00 \log \mathrm{CFU} / \mathrm{ml}$, from 3.72 to $5.19 \mathrm{log} \mathrm{CFU} / \mathrm{ml}$, and from 2.58 to $3.95 \log \mathrm{CFU} / \mathrm{ml}$, respectively). After six storage days, in all milk samples microorganism growth was observed. The highest colony counts of bacteria occurred in pasteurised milk and HP 250/15 treated milk, respectively $5.70 \log \mathrm{CFU} / \mathrm{ml}$ and $5.81 \log \mathrm{CFU} / \mathrm{ml}$. After seven storage days, fermentation had stopped in all milk treatments.

A significantly higher colony count $(p<0.05)$ was observed in the HP 250/15 treatment $-6.48 \log \mathrm{CFU} / \mathrm{ml}$. The HP $550 / 3^{\prime}$ treatment showed the best result: the number of microorganisms was $3.9 \log \mathrm{CFU} / \mathrm{ml}$. However, colour and consistency changes were found also in this treatment and the experiment was halted.

The effect of high pressure processing on total plate count in control milk, pasteurised (HP) and pasteurised-HP treated (TPHP) milk treatments is shown in Figure 2.

The research results showed that after treatment microorganism counts were decreased in all analysed milk samples, but in the TPHP 550/3 treatment growth of bacteria was
Fig. 1. Total bacteria count in heat pasteurised (TP) and HP treated milk samples during storage.

Fig. 2. Total bacteria count in pasteurised (TP) and pasteurised-HP treated (TPHP) milk samples during storage. not observed. The total bacteria count in milk samples processed with g TP and HP (TPHP 250/15', TPHP 400/3', and TPHP 400/15') treatments were similar, respectively, 2.53 $\log \mathrm{CFU} / \mathrm{ml}, 2.51 \log \mathrm{CFU} / \mathrm{ml}$, and $2.43 \log \mathrm{CFU} / \mathrm{ml}$. Even after two storage days, no bacterial growth was observed in the TPHP 550/3 treatment. After two storage days, the largest colony count was found in the TPHP 250/15 treatment - $2.59 \log \mathrm{CFU} / \mathrm{ml}$. After four days, in TPHP processed milk the number of microorganisms had increased in all samples. Also, there was one colony forming unit in the TPHP 550/3 treatment. After five days of storage, in all milk treatments (TPHP 250/15', TPHP 400/3`, TPHP 400/15 , and TPHP550/3') there was rapid growth of microorganisms (respectively, from 2.69 to $4.02 \log \mathrm{CFU} / \mathrm{ml}$, from 2.68 to $3.95 \log \mathrm{CFU} / \mathrm{ml}$, from 2.51 to $3.70 \mathrm{log}$ $\mathrm{CFU} / \mathrm{ml}$, and from 1.00 to $2.00 \log \mathrm{CFU} / \mathrm{ml})$. After six days, the highest colony counts of bacteria was observed in pasteurised milk, TPHP 250/15', and TPHP400/3' treatments, respectively, $5.70 \log \mathrm{CFU} / \mathrm{ml}, 4.70 \log \mathrm{CFU} / \mathrm{ml}$ and 4.65 $\log \mathrm{CFU} / \mathrm{ml}$. After milk storage for seven days, in the TPHP treatments the number of microorganisms had rapidly increased in all samples. The largest colony count was observed in the TPHP 250/15 treatment - 5.40 $\mathrm{log}$ CFU/ml, and the TPHP 550/3 treatment showed the best result: the number of microorganisms was $3.9 \log \mathrm{CFU} / \mathrm{ml}$.

Inactivation by high-pressure treatments of Escherichia coli in analysed milk samples is presented in Table 2. Coliforms were discovered in three milk samples. 
ESCHERICHIA COLI PRESENCE IN MILK SAMPLES

\begin{tabular}{c|c|c|c|c|c}
\hline Control & TPMilk & $\begin{array}{c}\text { HPMilk } \\
250 / 15\end{array}$ & $\begin{array}{c}\text { HPMilk } \\
400 / 3^{\star}\end{array}$ & $\begin{array}{c}\text { HPMilk } \\
400 / 15^{\star}\end{array}$ & $\begin{array}{c}\text { HPMilk } \\
550 / 3^{\wedge}\end{array}$ \\
\hline+ & - & + & + & - & -
\end{tabular}

\section{DISCUSSION}

According to the Regulation (EC) No. 853/2004 of the European Parliament and of the Council of 29 April 2004 laying down specific hygiene rules for food of animal origin, the number of microorganisms in milk must not exceed $100000 \mathrm{CFU} / \mathrm{ml}$. The TPC in the control sample was $130000 \mathrm{CFU} / \mathrm{ml}$, which exceeded the permitted limit and thus provided an excellent possibility to study the efficiency of HPP. Other studies found that only $41.8 \%$ of raw milk samples do not exceed the specified maximum levels of microbiological contamination (Konošonoka and Jemeljanovs, 2002), which confirms our results. Contamination of raw milk and the high bacteria count in milk originates from milking wet dirty udders, the used milking system, the cooling and storage temperature and the holding time (Salman and Hagar, 2013). For ensuring high quality milk, it is not enough to cool milk to $4-6{ }^{\circ} \mathrm{C}$ in a short period of time (20-30 $\mathrm{min})$. The initial quality of milk depends on: observing sanitary/hygienic rules during milking, cleanness of equipment and observation of personal hygienic rules (Zagorska, 2007).

In pasteurised milk, TPC decreased significantly $(p<0.05)$ compared with the control sample (1.53 log CFU/ml) by $97.1 \%$. According to the literature, after heating the percentage microbial reduction is $97.3-99.9 \%$. Thus, the study showed that pasteurisation did not result in a suitable effect. This can be explained by the high TPC before treatment, which may affect the count of the bacteria after treatment (Salman and Hagar, 2013) and the uncertainty of the pasteurisation process (inaccurately determined temperature, the duration of the pasteurisation, and cooling rate).

A reduction of TPC of $1.51 \log \mathrm{CFU} / \mathrm{ml}$ by $\mathrm{HP}$ at $250 \mathrm{MPa}$ (with holding time $3 \mathrm{~min}$ ) at room temperature was observed in this study, whereas even $\sim 5 \log$ and $\sim 3 \log$ $\mathrm{CFU} / \mathrm{ml}$ inactivation were observed by $\mathrm{HP}$ of raw milk respectively at $250 \mathrm{MPa}$ at $55{ }^{\circ} \mathrm{C}$ or $70{ }^{\circ} \mathrm{C}$ (Smiddy et al., 2007 ) and at $250 \mathrm{MPa}$ at $45^{\circ} \mathrm{C}$ (Hayes et al., 2005), indicating the importance of temperature in HP-induced inactivation of bacteria. Differences among results can be explained by the low temperature regime used during HP processing in this study. In other HP milk treatments (400/3`, 400/15', and 550/3'), it should be noted that bacterial load reduction was respectively $1.63 \log \mathrm{CFU} / \mathrm{ml}, 2.55 \log \mathrm{CFU} / \mathrm{ml}$, and $3.58 \log \mathrm{CFU} / \mathrm{ml}$. Evidently, HP treatment at $400 \mathrm{MPa}$ ensures the same quality as pasteurisation. According to the literature, HPP is equally effective in destroying pathogenic and spoilage microorganisms (Chawla et al., 2011). Significant decrease $(p<0.05)$ of colony forming units was established in samples processed by combining two treatment types: pasteurisation and HPP. Application of $550 \mathrm{MPa}$ for 3 min completely inactivated microorganisms in TPHP milk.

During storage, the population of microorganisms grew progressively in all HP and TPHP treated milk samples. Rapid growth trends were observed in all samples after five days of storage. Growth of bacteria in HP treated milk depended on the pressure and holding time of treatment. After seven days of storage, the growth rate of bacteria was in the following order: $250 \mathrm{MPa} / 3^{2}<400 \mathrm{MPa} / 3^{2}<400 \mathrm{MPa} / 15^{\prime}<$ $550 \mathrm{MPa} / 3^{\circ}$. Similar results were obtained in TPHP milk samples. The minimum treatment regime for shelf-life extension of pasteurised skimmed milk was determined: pressure not less than $400 \mathrm{MPa}$ and a holding time of at least 15 minutes. According to the obtained results of the study it can be concluded that for ensuring milk quality for a long period of time, it is more effective is to combine HP with preceding thermal treatment (pasteurisation). However, it would be necessary to note some drawbacks: 1) from an economic point of view, for milk producers would not be profitable to make the double processing of product; and 2 ) the loss of sensory properties and biologically active substances in the product during pasteurisation.

Another indicator of milk quality and sanitary conditions on the farm is presence of Escherichia coli in the milk. The coliform count is related to the unsanitary milking process and the dirty cow's environment (Salman and Hagar, 2013). According to the literature (Hayes et al., 2005; Smiddy et al., 2007; Chawla et al., 2011; Gustavo et al., 2014), the complete destruction of $E$. coli can be reached either in low or medium pressure mode, while increasing the processing temperature and time, or at a higher pressure (above 500 $\mathrm{MPa}$ ) without additional time and temperature rise. According to other data on HP processing of milk (strawberry skimmed milk), under pressures $200 \mathrm{MPa}$ (with holding time $15 \mathrm{~min})$ and $600 \mathrm{MPa}(1 \mathrm{~min})$ pathogenic microorganisms were not identified (Tadapaneni et al., 2014). In this study, Enterobacteriacea spp. were identified in three (control, HPMilk 250/15', and HPMilk 400/3') of six milk treatments. According to the obtained data it can be concluded that some of the high pressure regimes $(250 \mathrm{MPa} / 15$ and $400 \mathrm{MPa} / 3^{\prime}$ ) are insufficient and cannot be used for inactivation of coliforms in milk.

The data presented in this study clearly indicate a very limited microbial shelf-life of HPP treated milk. This can be explained by the low selected pressure mode and too short processing time. Further research should be conducted to determine the optimal treatment parameters for preservation of biologically active substances and nutritional value of milk and for achieving maximum milk shelf-life.

\section{ACKNOWLEDGEMENTS}

The study was supported by the National Research Programme "Agricultural Resources for Sustainable Pro- 
duction of Qualitative and Healthy Foods in Latvia" (AgroBioRes) (2014-2017), Project No. 4 "Sustainable use of local agricultural resources for qualitative and healthy food product development" (FOOD).

\section{REFERENCES}

Bello, E., Martínez, G., Ceberio, B., Rodrigo, D., López, A. (2014). High pressure treatment in foods. Foods, 3 (3), 476-490.

Chawla, R., Patil, G., Singh, A. (2011). High hydrostatic pressure technology in dairy processing: A review. J. Food. Sci. Technol., 48 (3), 260-268.

Chopde, S. S., Deshmukh, M. A., Kalyankar, S. D., Changade, S. P. (2014). Applications of high pressure technology for milk processing. Res. J. Animal Husbandry Dairy Sci., 5 (2), 143-147.

Considine, K., Kelly, A., Fitzgerald, G., Hill, C., Sleator, R. (2008). High-pressure processing - effects on microbial food safety and food quality. FEMS Microbiol. Lett., 281 (1), 1-9.

Fitria, A., Buckow, R., Singh, T., Hemar, Y., Kasapis, S. (2015). Colour change and proteolysis of skim milk during high pressure thermal-processing. J. Food Eng., 147, 102-110.

Ghasemkhani, N., Morshedi, A., Poursharif, Z., Aghamohammadi, B., Akbarian, M., Moayedi, F. (2014). Microbiological effects of high pressure processing on food. J. Biodivers. Environ. Sci., 4 (4), 133-145.

Gustavo, G., Espejo, A., Hern, M. M. (2014). Inactivation of Bacillus spores inoculated in milk by Ultra High Pressure Homogenization. Food Microbiol., 44, 204-210.

Hayes, M. G., Fox, P. F., Kelly, A. L. (2005). Potential applications of high pressure homogenisation in processing of liquid milk. J. Dairy Res., 72 (1), $25-33$

Heinz, V., Buckow, R. (2009). Food preservation by high pressure. J. Consumer Protect. Food Safety, 5 (1), 73-81.

Hite, B. H. (1899). The effect of pressure in the preservation of milk. West Virg. Agricult. Exper. Station Bull., 58, 15-35.

Konošonoka, I. H., Jemeljanovs, A. (2002). Piena un gaḷas mikrobioloǵiskais piesārn,ojums to realizācijas vietās. Starptautiskā konference "ECO-Balt 2002", Rīga, 2002. gada, 7.- 8. jūnijā. http://doi.org/http://ecobalt.ktf.rtu.lv/request.php?197 (last accessed 20 September 2016)

Muñoz-Cuevas, M., Guevara, L., Aznar, A., Martínez, A., Periago, P. M., Fernández, P. S. (2013). Characterisation of the resistance and the growth variability of Listeria monocytogenes after high hydrostatic pressure treatments. Food Control, 29 (2), 409-415.

Naik, L., Sharma, R., Rajput, Y. S., Manju, G. (2013). Application of high pressure processing technology for dairy food preservation - future perspective?: A Review. J. Animal Prod. Adv., 3 (8), 232-241.

Patterson, M. F. (2005). Microbiology of pressure-treated foods. J. Appl. Microbiol., 98 (6), 1400-1409.

Rodriguez, E., Arques, J. L., Nuñez, M., Gaya, P., Medina, M., Nun, M. (2005). Combined effect of high-pressure treatments and bacteriocin-producing lactic acid bacteria on inactivation of Escherichia coli O157: H7 in raw-milk cheese combined effect of high-pressure treatments and bacteriocin-producing lactic acid bacteria on inact. Appl. Environ. Microbiol., 71 (7), 3399-3404.

Salman, M. A., Hagar, M. (2013). Some bacterial and physical quality of pasteurized milk in Khartoum. J. Appl. Industr. Sci., 1 (2), 30-37.

Smiddy, M. A., Martin, J.-E., Huppertz, T., Kelly, A. L. (2007). Microbial shelf-life of high-pressure-homogenised milk. Int. Dairy J., 17 (1), 29-32.

Tadapaneni, R. K., Edirisinghe, I., Burton-Freeman, B. (2014). High-pressure processing, strawberry beverages, and composition of "bioactives.' In: Preedy, V. (Ed.). Processing and Impact on Active Components in Food. Academic Press, pp. 619-627.

Udabage, P., Augustin, M., Versteeg, C., Puvanenthiran, A., Yoo, J., Allen, N., Kelly, A. (2010). Properties of low-fat stirred yoghurts made from high-pressure-processed skim milk. Innov. Food Sci. Emerg. Technol., 11 (1), 32-38.

Yaldagard, M., Mortazavi, S., Tabatabaie, F. (2008). The principles of ultra high pressure technology and its application in food processing/preservation: A review of microbiological and quality aspects. Afr. J. Biotechnol., 7 (16), 2739-2767

Zagorska, J. (2007). The evaluation of organic milk quality. Summary of Doctoral Thesis, Latvia University of Agriculture, Jelgava, Latvia. 47 pp.

Zhang, H., Mittal, G. S. (2008). Effects of high-pressure processing (HPP) on bacterial spores: An overview. Food Rev. Int., 24 (3), 330-351.

Received 4 October 2016

Accepted in the final form 29 November 2017

\section{AUGSTĀ SPIEDIENA IETEKME UZ VĀJPIENA MIKROBIOLOG̣ISKO KVALITĀTI}

Piena termiskās apstrādes režīmi (pasterizācija, sterilizācija, īpaši augsta temperatūra) negatīvi ietekmē produkta sastāvdaḷas: izmainās piena uzturvērtība un sensorās īpašības, zūd vērtīgie vitamīni. Apstrāde augstā spiedienā ir viena no alternatīvām pārtikas produktu termiskai apstrādei. Šo tehnolog̣iju var izmantot piena produktu rūpniecībā, lai palielinātu produkta mikrobioloǵisko drošību un saglabātu tā bioloğiski aktīvās vielas. Jautājums par augstspiediena apstrādes efektivitāti produkta mikrobioloğiskās kvalitātes nodrošināšanā vēl joprojām ir diskutabls. Pētījuma mērkis bija izvērtēt augstspiediena tehnoloǵijas ietekmi uz vājpiena mikrobioloğisko kvalitāti. Tika analizēti un salīdzināti svaiga vājpiena, pasterizēta $\left(78^{\circ} \mathrm{C}, 15-20 \mathrm{~s}\right)$, apstrādāta augstā spiedienā (250 MPa, 15 min; $400 \mathrm{MPa}, 3$ min; 400 $\mathrm{MPa}, 15 \mathrm{~min} ; 550 \mathrm{MPa}, 3 \mathrm{~min}$ ) un kombinētajā režīmā (pasterizācija un augstais spiediens) vājpiena paraugi. Visiem paraugiem tika noteikts mezofīli aerobo un fakultatīvi anaerobo mikroorganismu (MAFAM) skaits (LVS ISO 4833-1: 2013). Ievērojams $(p<0.05$ ) koloniju veidojošo vienību samazinājums tika konstatēts vājpiena paraugos, kuri tika pakḷauti kombinētai apstrādei. Lai pagarinātu vājpiena uzglabāšanas laiku, minimāliem produkta augstspiediena apstrādes parametriem ir jābūt sekojošiem: spiediens nav mazāks par 400 MPa un izturēšanas laiks vismaz 15 minūtes. 